\title{
DESIGN OF A POWER SYSTEM (SOLAR-DIESEL GENERATOR) FOR A GARMENT INDUSTRY AND LOAD OPTIMIZATION
}

\author{
Ahnaf Tahmid Nahian, Md.Tahmid Farhan Himel \\ Institute of Energy, \\ University of Dhaka, Bangladesh \\ Mahmudul Hasan, Nafeez Rahman, Chowdhury Akram Hossain \\ Department of EEE, \\ American International University-Bangladesh
}

\begin{abstract}
Due to adverse effect of global warming and environmental pollution, future world is looking for decontaminated green energy resources for power generation. Economy of today's world is based on commercial activities and rapid industrialization. To ensure sustainable economic activity we need to fulfil the energy demand of equipment as well as to serve the automation technology of industrial sector. This results an excess pressure on electricity demand significantly. In spite of many restrictions and proper technical support Bangladesh is looking forward to extract energy from its available renewable resources like other countries. Hybrid power system is a good choice to serve this purpose. This work mainly emphasis on the design and feasibility study of hybrid power system in the context of a particular garment industry, as the garments are the major source of foreign currency and employment in our country. The system is comprised of solar PV and diesel generator. Cost analysis and load optimization is done by HOMER Pro. System validity and advantages are also discussed in explicit way.
\end{abstract}

Keywords - Solar power, Hybrid system, Garment industry

\section{INTRODUCTION}

Solar, biomass \& wind are the extended aspirant among the easily reached renewable energy sources in Bangladesh. Putatively, Bangladesh gets 69,751 TWh energy every year which is 3000 times greater than the traditional electricity generation [1]. In Bangladesh yearly, solar radiation has a regular power density of $100-300 \mathrm{~W} / \mathrm{m}^{2}$ which can produce $100 \mathrm{MW}$ electricity with an area of $3-10 \mathrm{~km}^{2}$ with a panel of $10 \%$ efficiency [2]. In a year with $6.8 \%\left(10,000 \mathrm{~km}^{2}\right)$ of the land of Bangladesh, per capita $3000 \mathrm{kWh}$ electricity decree can be achieved [3]. The government of Bangladesh acmes the necessity of installing rooftop solar PV system due to the paucity of land. Researcher have found that $1000 \mathrm{MW}$ of solar PV electricity with $75 \mathrm{~W}$ capacity of the solar module can be produced by the total accessible sunny rooftops area in Dhaka city which is $10.554 \mathrm{~km}^{2}$. [4] The efficiency of solar PV decreases significantly because of non-linear characteristics of solar PV and atmospheric conditions which comprises the variation of irradiation as well as the different weather condition. [5] Depletion of power, more installation of PV panel, premature battery failure, capacity loss, lack of proper end-of-charge, higher voltage can be reduced by using MPPT solar charge controller with PV system. [6, 7] There is no doubt that the power demand of Bangladesh is increasing day by day. There should be a balance between production and supply in the economy of a country. Excess demand requires greater production capacity that can create power crisis. Bangladesh is a developing country with a reduced production of electricity due to traditional power plants with de-rated machineries. According to a survey, gap between the produced power and demanded power is about 1000-1500 MW [8]. For this measurable condition, people of remote areas as well as the industries are deprived of grid connection. Many industries in our country are using captive power (natural gas) to meet their energy demand. But this is not possible in everywhere (due to lack of capital, space, technical skill, proper maintenance etc.). Considering the current situation, one possible solution of this problem is to produce electricity from hybrid distributed systems from different energy resources. This type of system can also be integrated to national grid with proper mechanism. Ready Made garments are the most discernible sector of largest foreign currency of country. According to a survey of World Bank about $81.69 \%$ of total GDP are covered by this sector [9]. It contributes almost $45 \%$ of total employment and 5\% of total national income. The production of textile industry often requires a high level of energy consumption with a lowest efficiency in energy consumption [10]. Higher competitiveness and productivity result more benefits. So from business point of view it's important to minimize energy cost and energy consumption 


\section{International Journal of Engineering Applied Sciences and Technology, 2019 \\ Vol. 4, Issue 8, ISSN No. 2455-2143, Pages 1-8 \\ Published Online December 2019 in IJEAST (http://www.ijeast.com)}

and thus increase energy efficiency. The objective of the work is to design a solar hybrid system (with a diesel generator) to ensure sustainable energy supply for a particular garment industry (Knit Concern's Ltd.). In terms of reliability, better services, operational life, efficiency, the hybrid system has brought forth a modified perfection in electricity generation process. The concept of solar- diesel generator to be used as hybrid system is becoming popular day by day, due to its frequent usability and cost effectiveness. Solar power is often considered as the most economical alternative solution to power crisis. Solar irradiation which is both free and abundant by nature that can profitably be used in many applications along with conventional fuel generators. The price of fossil fuel is unreliable and depends on many facts (including both purchase and carrying cost). Implementation of both system together can significantly reduce the system operating cost as well as the emission of $\operatorname{co} 2$ gas in nature.

\section{DESIGN OVERVIEW}

The purposed work was to design a power system for a particular garment industry (Knit Concern Ltd.). Exact location of the industry is on the bank of Shitalakhya River, Godnail, Narayanganj. This industry covers a premises of 18 acres. It consists of different sections such as Ginning, Spinning, Dying, Washing/ Hydro Section, Processing, Weaving, Knitting, Cutting, Stitching etc. with a variation in load. Since the production of the industry is too large, so the amount of load is also high respectively. The prime goal was to design the system at reduced cost and energy consumption without affecting the productivity. The necessary data was collected to found out the most suitable unit, that's more techno-economically feasible for our proposed system compared to others. Thus by considering the audits, it was found that the apparel division (cutting \& stitching) is much suitable to serve the purpose.

The system is oversize type consists of both solar PV and diesel generator. Solar energy can be easily extracted and can be stored in a battery to serve at night by solar cell with less maintenance cost. Due to high load management purpose, a diesel generator is added with solar PV. Both are chosen to serve the purpose of power source of the system, because of their ease of use. They will operate simultaneously. By applying this method the cost can be minimized of the system for a long term satisfactory operation. The components of the system include a diesel generator $(30 \mathrm{~kW})$, converter, generic flat PV modules and system load. There were no storage mechanism in our system, because the capacity of diesel generator is such that it can supply the load without the association of solar PV, during the absence of solar irradiation. The system was oversized to feed the industrial load. Total system capacity is $369 \mathrm{kWh}$ /day with a peak value of 55.94 $\mathrm{kW}$. The schematic diagram of the system is given below.
The system is an off grid system. The system is especially designed to supply the load of two floors (light and fans) of the apparel division. The system is designed according to the energy consumption of the load. The value was computed as Energy consumed by lights $=12 * 12 * 65 * 2=18.72=19 \mathrm{~W}$ Energy consumed by fans $=12 * 7 * 75 * 2=12.6=13 \mathrm{~kW}$ So the total energy consumption is $=19 \mathrm{~kW}+13 \mathrm{~kW}=32 \mathrm{~kW}$. The system is able to supply $32 \mathrm{~kW}$ at peak hour. Extra capacity can be added to the system by providing additional sources.

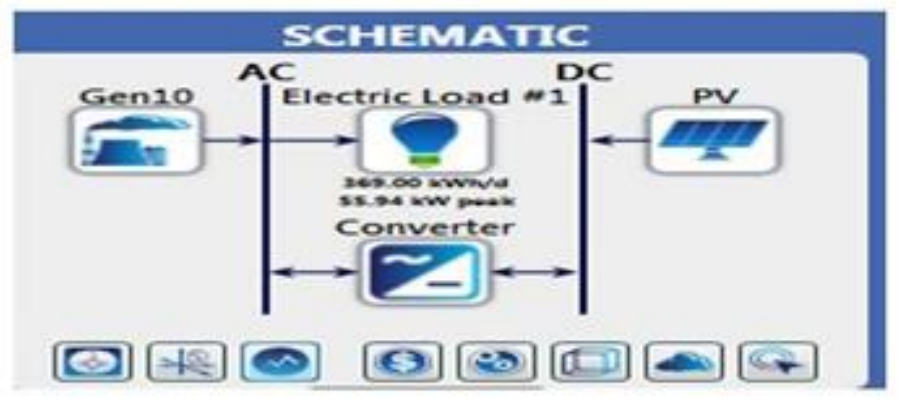

Fig.1. Homer Pro system model

The system capacity with respect to total amount of load is given as a pie chart as shown above. Though it covers a very small portion of total load, still it's able to provide continuous supply to desired load without any interruption. The system would be implemented on the rooftop of the building. Generators should be placed on shaded area. To design this system 269 piece PV modules, three diesel generators/ one $(30 \mathrm{~kW})$ generator and one converter was required. Total net present cost of the system was therefore \$2, 48, 052 with liveliest cost of electricity $\$ 0.1293$ and operating cost $\$ 13,569$.

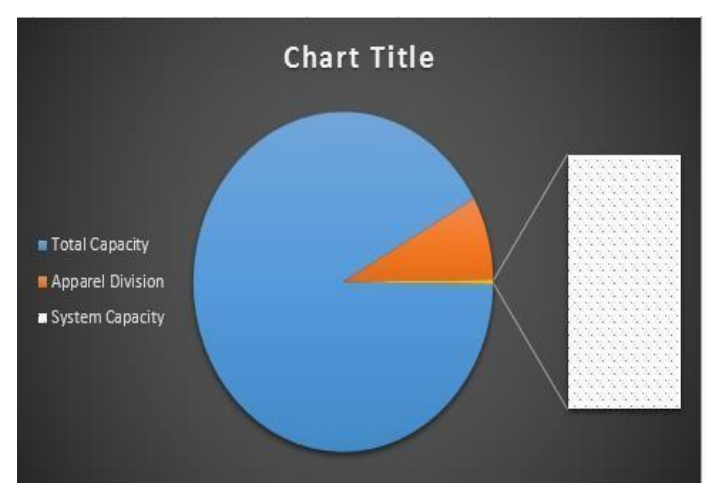

Fig 2 Portion of load covered by the System 
Table 1 Price and rating of the components are given below as a tabular form.

\begin{tabular}{ccc}
\hline Component Name & Capacity & Price \\
\hline PV modules & $93 \mathrm{~kW}$ & $\$ 47,451$ \\
Diesel Generator & $30 \mathrm{~kW}$ & $\$ 2,100$ \\
Converter & $52 \mathrm{~kW}$ & $\$ 2,600$ \\
\hline
\end{tabular}

The figure shown below represents the block diagram of the system.

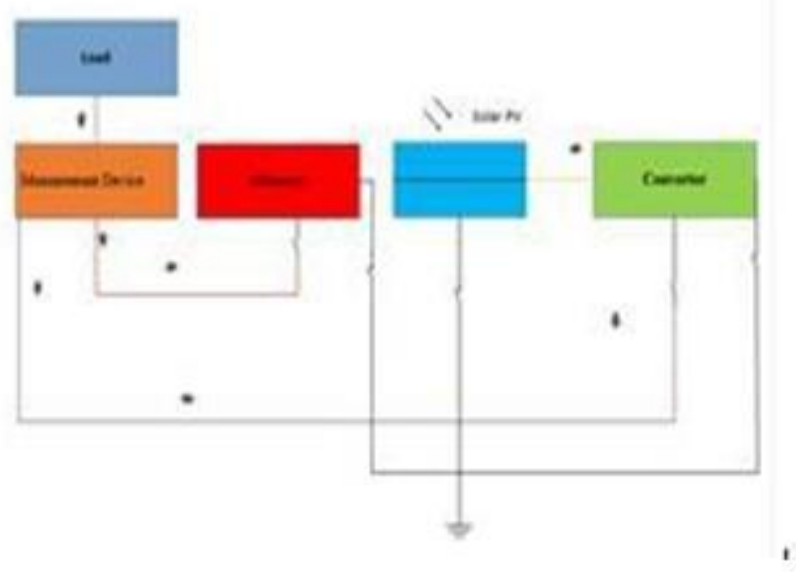

Fig.3. System Block Diagram

It features five components: Alternator, Converter, PV modules, measurement device and respective loads. Current is going from alternator to measurement device directly. Output of solar PV first transfers to converter. Converter converts it into useful ac current for typical ac load. The relay connected to the alternator, PV modules and converter will bypass the excess current during overflow. Arrow sign shows the direction of current. The system provides switching mechanism that can make contact between load and generating device to provide constant supply.

\section{ENERGY RESOURCES AND LOAD PROFILE}

\section{A. Load Profile and Collected Data}

A distinctive load profile has been made according to the data which was collected. To supply the load of apparel division of the garment industry, a power supply of $369 \mathrm{kWh} /$ day on average with a peak demand of $55.94 \mathrm{~kW}$ is required. The load factor is 0.27 . Load factor is the division of average load by peak value. The load operates for 9 hours (working hours). 2 hours are specially considered for overtime workers. The work load is maximum between 10 A.M- 12 P.M. Variation in load is not so high because the load type is industrial. The value is almost constant

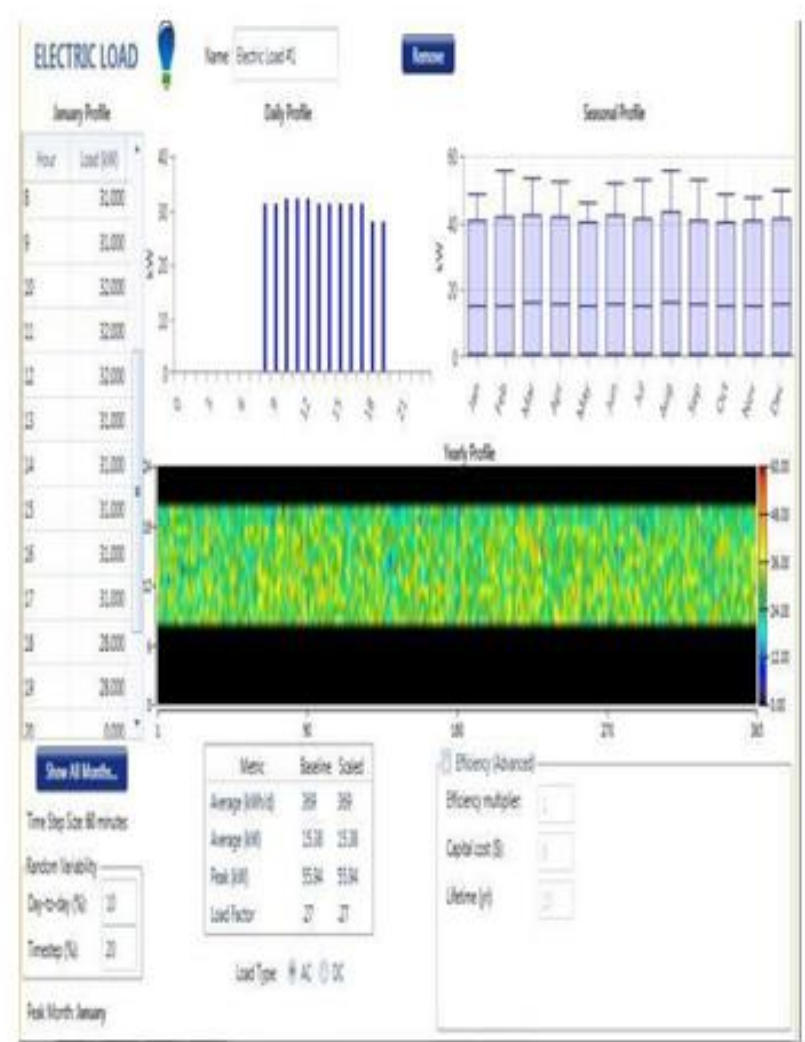

Fig 4 Electric Load Profile

$$
\text { Daily Profile }
$$

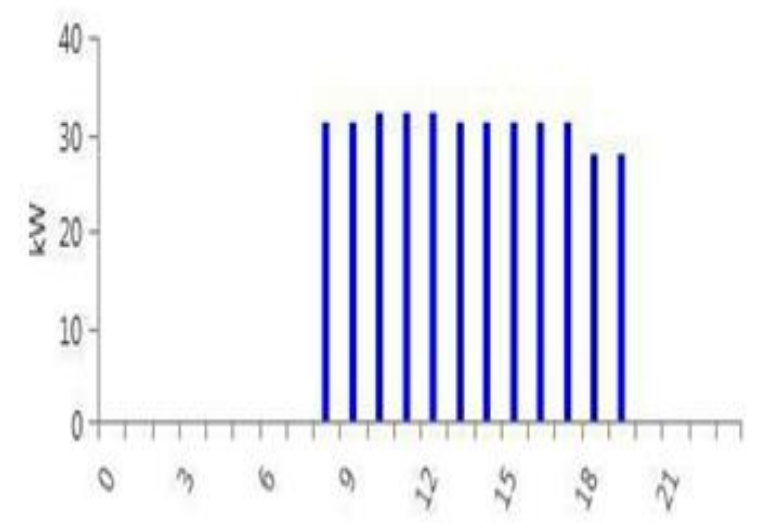

Fig.5. Daily Load Profile

\section{B. PV System Sizing}

Actual geographical coordinates of that industry is $23^{\circ} 39^{\prime}$ On North, $90^{\circ} 31^{\prime}$ On South. The value of solar radiation $\left(\mathrm{kWh} / \mathrm{m}^{2} /\right.$ day) are computed by HOMER Pro software via internet. Space required by solar panel is quite higher compared to other power generating system. So this fact 


\section{International Journal of Engineering Applied Sciences and Technology, 2019 \\ Vol. 4, Issue 8, ISSN No. 2455-2143, Pages 1-8 \\ Published Online December 2019 in IJEAST (http://www.ijeast.com)}

should be considered before implementation of Solar PV. According to plant capacity, each kW PV requires 107 sq. feet of area. By considering the solar radiation photovoltaic system size are chosen between a ranges of $80-93 \mathrm{~kW}$ capacity with a derating factor of $90 \%$. Lifetime of the photovoltaic system is 25 years. Total capital cost of the system is $\$ 47,451$. The replacement and O\&M cost is considered $\$ 0$, because the project lifetime is equal to the lifespan of solar PV.

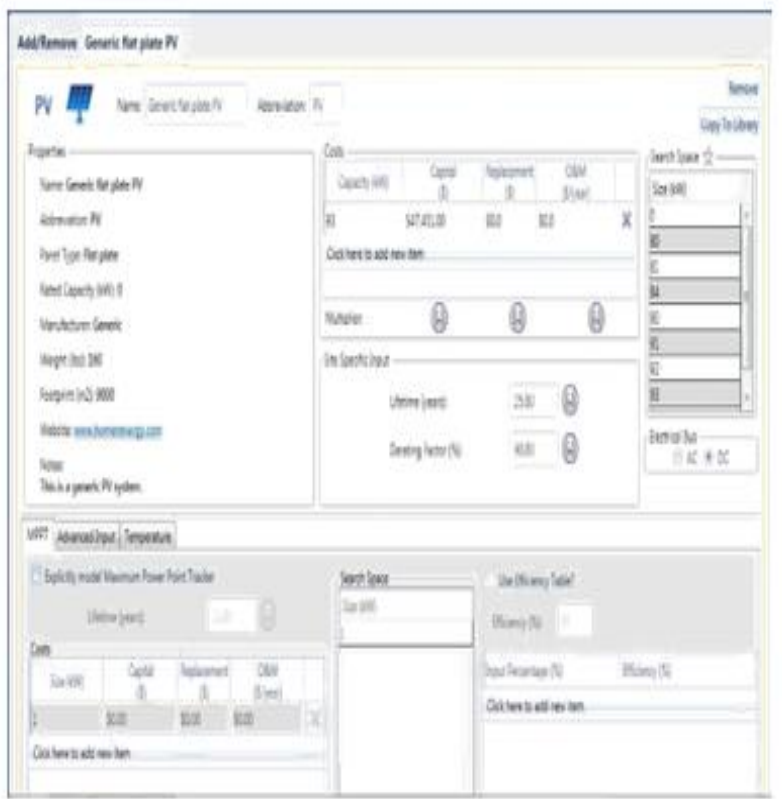

Fig.6. PV profile

\section{Generator Sizing}

Generator with a $30 \mathrm{~kW}$ capacity is required to make the system feasible. Generator is provided in such a way, so that it can jointly operate with PV to supply the load. Generator capacity is chosen $30 \mathrm{~kW}$. Value of the generator is $\$ 700$ $(10 \mathrm{~kW})$. Operation and maintenance cost is chosen $\$ 0.030$. Generator sizes are specified in search space. Price of fuel is considered $\$ 0.837 / \mathrm{L}$. Total operating hours of generator 219,000 .

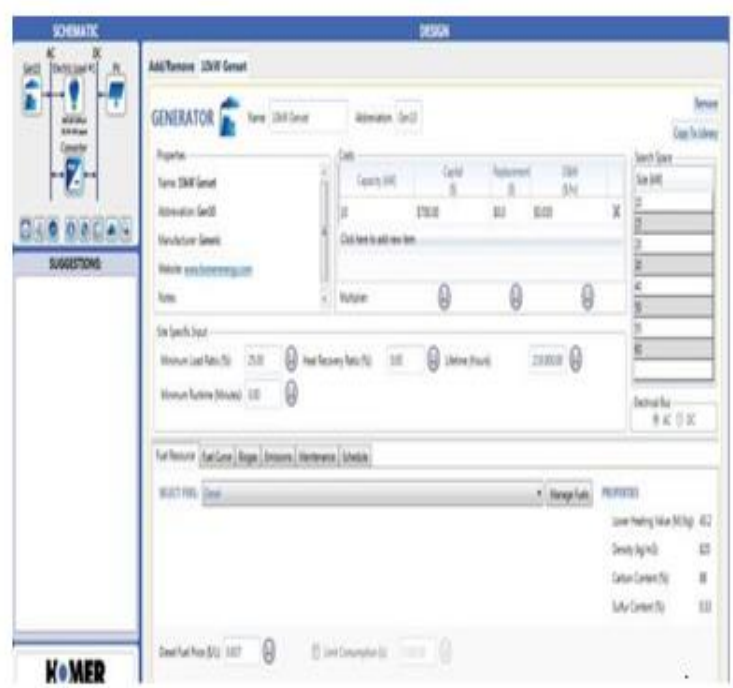

Fig 7: Generator Profile

\section{Converter SizingDesign}

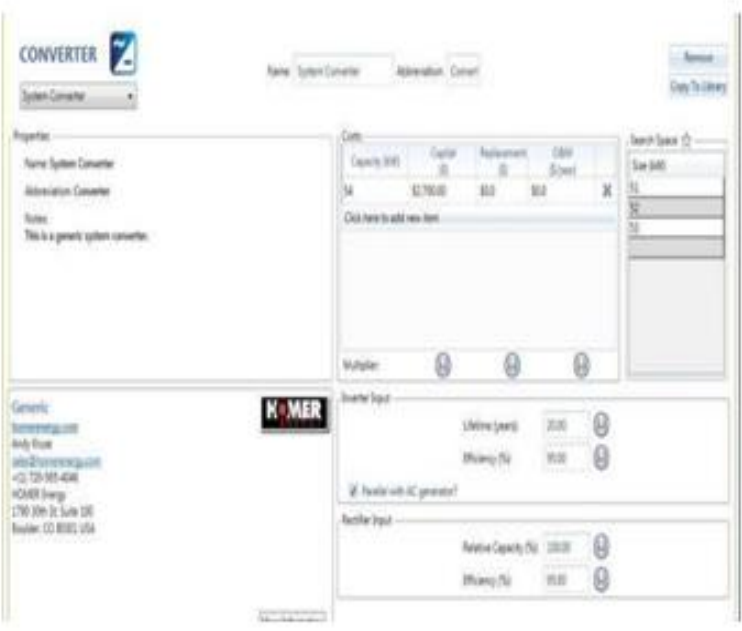

Fig 8 Converter Profile

Converter configuration is shown in above figure. Capacity of converter is chosen $54 \mathrm{~kW}$ with an efficiency of $95 \%$. Initial cost of the converter is $\$ 2700$.

\section{SimUlation AND OUTPUT}

\section{A. Simulation Result}

By providing necessary data including the component cost and monthly data's of resources in HOMER simulation tool, simulation were initiated. The objective of this simulation is to find the optimal size of the system. The exact size and 


\section{International Journal of Engineering Applied Sciences and Technology, 2019 \\ Vol. 4, Issue 8, ISSN No. 2455-2143, Pages 1-8 \\ Published Online December 2019 in IJEAST (http://www.ijeast.com)}

combination of the system was showed by HOMER Pro, after the simulation was completed. Results are given below.

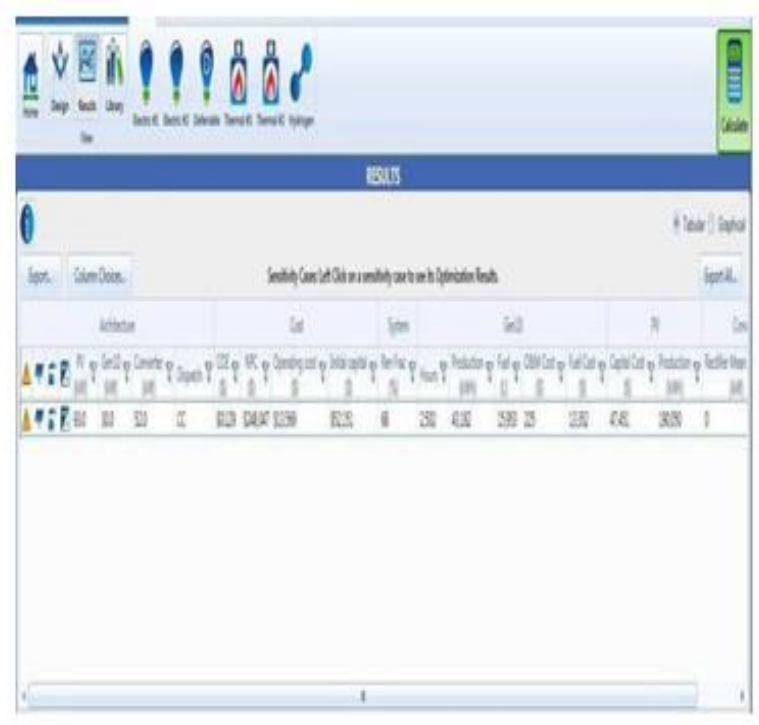

Fig 9 Simulation Output

From the figure, we can see that the cost of electricity (COE) which is the minimum cost of electricity is $\$ 0.129(10.21$ BDT; 1 USD $=79.21$ BDT). Total NPC is $\$ 2,48,047$. Operating cost is considered $\$ 13,569$. System is not totally noiseless and uncontaminated. This value is given by renewable fraction part of the system which is $68 \%$ in our case. Operating hours of generators are 2,502 with a production of $43,182 \mathrm{kWh}$. Total amount of fuel is $15,953 \mathrm{~L}$. Production of PV modules are 190,050 kWh. Values regarding the expense of $\mathrm{PV}$, generator and converter are given below in tabular form

Table 2 Cost of the system

\begin{tabular}{ccccc}
\hline Component & Cost & O\&M & Fuel & Salvage \\
\hline Diesel & $\$ 2,100$ & $\$ 3,249$ & $\$ 1,92,759$ & $(\$ 117)$ \\
Generator & & & & \\
& & & & \\
Converter & $\$ 2,700$ & $\$ 0$ & $\$ 0$ & $\$ 0$ \\
PV profile & $\$ 47,451$ & $\$ 0$ & $\$ 0$ & $\$ 0$ \\
System & $\$ 52,151$ & $\$ 3,249$ & $\$ 1,92,759$ & $(\$ 117)$ \\
\hline
\end{tabular}

\section{B. Electrical Output}

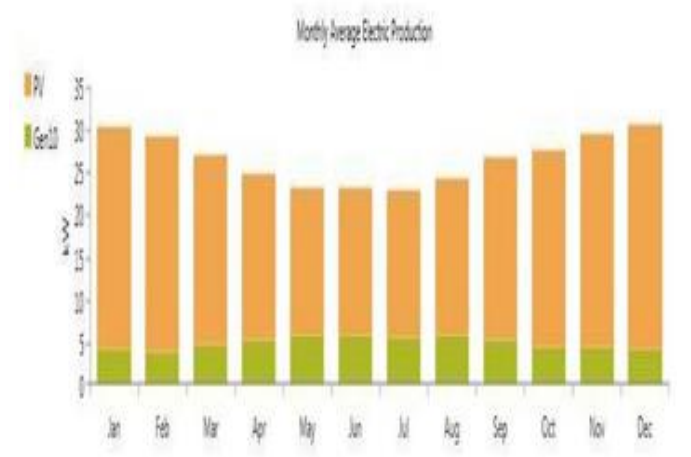

Fig.10. Monthly average Electrical Production

Above figure shows the electrical output on monthly basis. Upper portion represents the output from PV modules and the lower portion is the output of diesel generator. Electrical production from different resources and consumption percentage of different loads are shown below as table format.

Table 3 Production of the System

\begin{tabular}{ccc}
\hline Production & $\mathbf{k W h} /$ year & percentage \\
\hline PV panel & $1,90,050$ & $81.49 \%$ \\
Generator & 43,182 & $18.51 \%$ \\
Total & 233,232 & $100 \%$ \\
\hline
\end{tabular}

Table 4 Energy Consumptions of Load

\begin{tabular}{ccc}
\hline Consumption & $\mathbf{k W h} /$ year & Percentage \\
\hline AC primary Load & 132,892 & $100 \%$ \\
DC primary Load & 0 & $0 \%$ \\
Total & 132,892 & $100 \%$ \\
\hline
\end{tabular}

\section{Cash Flow}

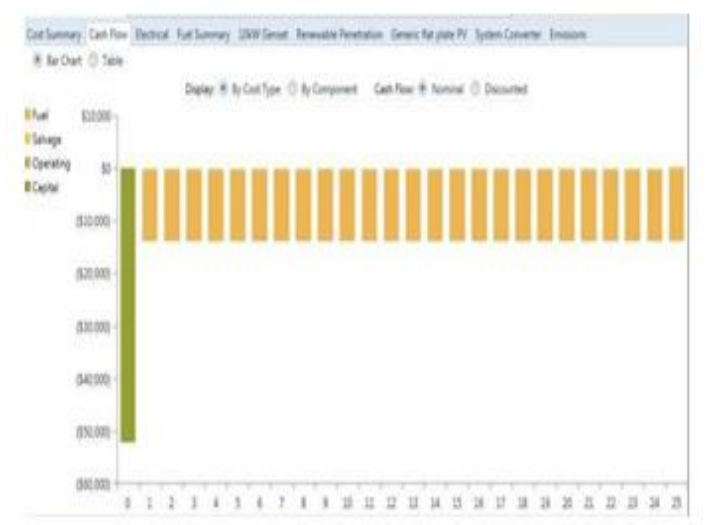

Fig.11. Cash Flow 


\section{International Journal of Engineering Applied Sciences and Technology, 2019 \\ Vol. 4, Issue 8, ISSN No. 2455-2143, Pages 1-8 \\ Published Online December 2019 in IJEAST (http://www.ijeast.com)}

Above figure shows the cash flow bar chart of the system. First bar represents the initial capital (installment cost). The other bars show the fuel cost to purchase the fuel. As it is showing that the fuel cost is almost constant during its period. This values are represented as a line graph below.

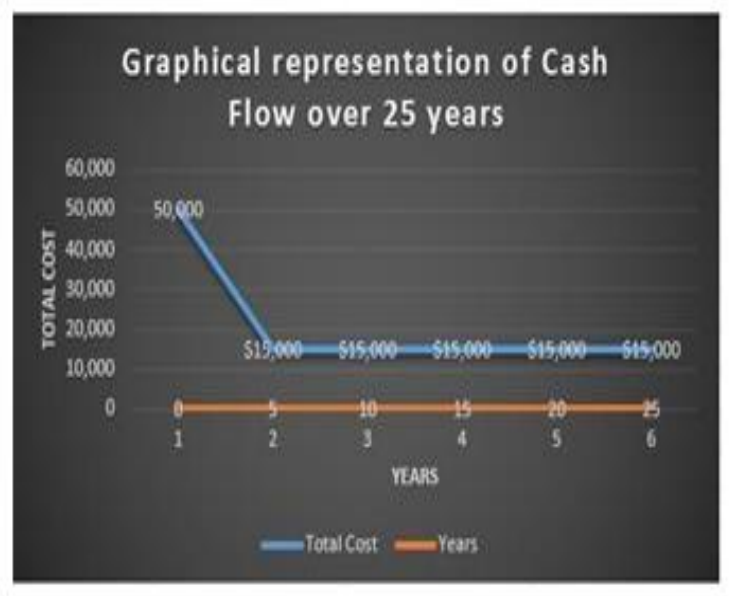

Fig.12. Cash Flow

\section{Power Output}

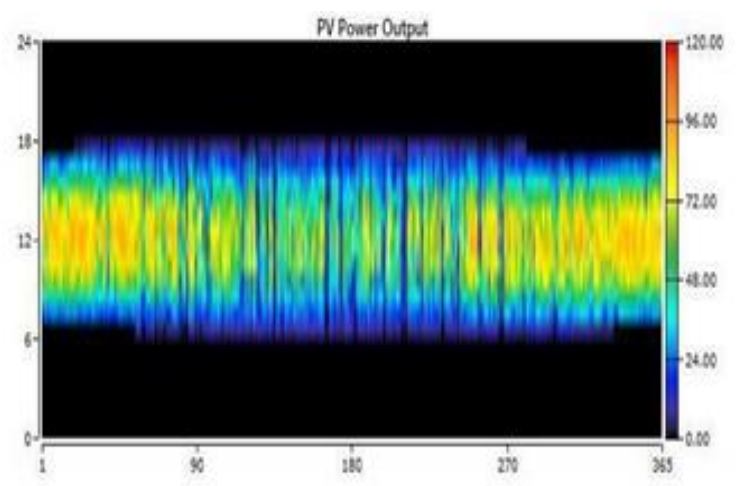

Fig.13. PV Power Output

Above figure shows the DMap of PV power output for 24 years and 365 days. The mean output is $520.68 \mathrm{kWh} /$ day with a capacity factor of $23.33 \%$. Total production is 190,050 $\mathrm{kWh} /$ year with a levelized cost of $0.0173 \$ / \mathrm{kWh}$.

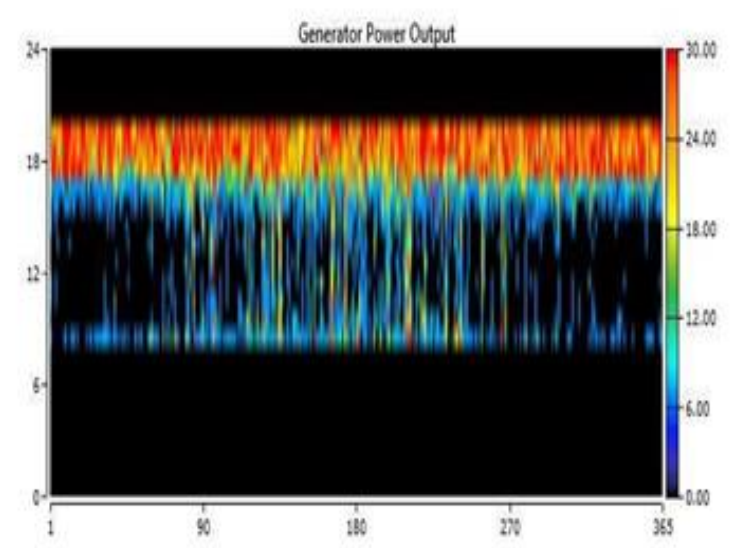

Fig.14. Generator Power Output

Same goes for generator. Maximum output of generator is 30 $\mathrm{kW}$ with a capacity factor of $16.4 \%$. Total electrical production is $43,182 \mathrm{kWh} /$ year with a marginal generation cost $0.239 \$ / \mathrm{kWh}$. Mean electrical efficiency is $27.51 \%$.

Finally the curve we found for AC primary load is shown below.

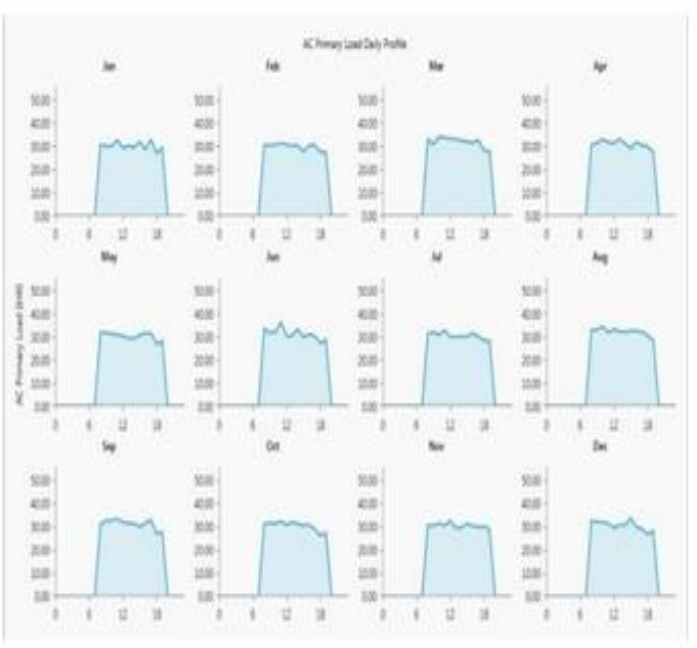

Fig.15 AC load for a Particular month 


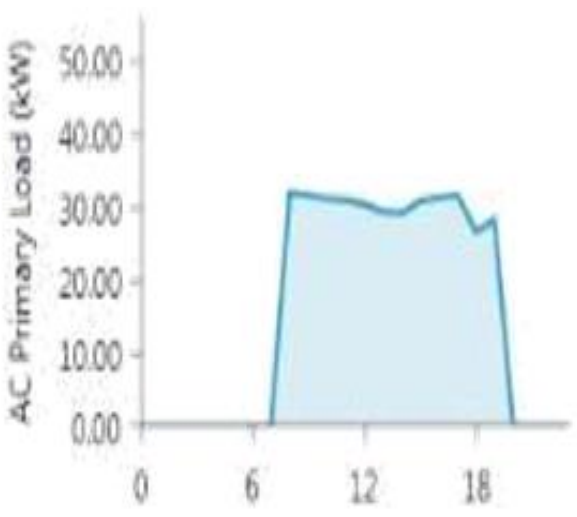

Fig.16. AC load for a Particular month

Therefore, considering the availability of potential resources economic feasibility of the system: $93 \mathrm{~kW}$ PV modules and 30 $\mathrm{kW}$ generator can be considered as follows

Total cost of the system $=\$ 2,48,047$

Maintenance cost of the generator $=\$ 3,249$

Operating years $=25$ years

No. of sunshine hours $=6$ hours.

Assuming PV array generates $90 \%$ of their rated capacity

So per day generation of the PV system $=93 * 6 * 0.90=502.2$ units

Per unit cost $($ for PV $)=\$ 47,451 /(25 * 365 * 502)=\$ 0.010$

Fuel cost of generator $=\$ 13,352$

Generator cost $=\$ 2,100$

Total cost $=\$ 13352+\$ 2,100+\$ 3,249=\$ 18,701$

Generation of the generator $=30 * 0.90=27$ units

Per unit cost $($ for generator $)=\$ 18,701 /(365 * 25 * 27)=\$ 0.07$

\section{LIMITATION}

Main problem of the system is that it's not entirely renewable resource based. So the operation of the system is not noiseless and pollution free. Besides the system couldn't manage the entire load of the industry. It only covers some particular loads of apparel division only. Another problem of the system is that there are some excess electricity due to oversizing of the system. But this problem can be solved by connecting them to some other loads, except the counted one.

\section{RECOMMENDATION}

In this study importance is given on the design of hybrid system. In most cases, industrial loads are supplied by captive stations, where natural gas is used as fuel. Due to enormous use of load for production purpose, the load consume very high energy. So there are many things that's need to be considered before designing a system for industrial load. Since the energy consumption is very compared to household appliances, the system should be designed in such a way, so that it can supply the load without any interruption in production. This system is able to supply sufficient energy required for suitable operation of load. Lifetime of the system is considered 20 years. The maintenance cost includes only the maintenance cost of generator. The mounting structure of the PV panels will be set on the rooftop of the building. The PV arrays will be arranged to their requirements. Spacing is important between two adjacent solar panels to ensure air circulation among them to reduce the amount of heating. Generator will be placed in a shaded area to prevent heat. Since the load will be used roughly throughout the year, the panels should be tilted at latitude.

\section{CONCLUSION}

Energy is the basic criterion for the upward spiral of the continuous prosperity of a country. Access of electricity is essential for communication, development, employment, healthcare, education etc. Like other developing countries, Bangladesh is switching from its traditional agro- based economy to industrialization process. Our govt. is offering various scheme and opportunities to continue this revolution. To ensure the incrimination of productivity- maintaining the standard of products, preservation of specific products and power processing equipment etc. are important. Power supply from a reliable source is an important catalyst for serving this purpose. This causes a burden on power plants and available fuel resources of our country. To solve the scarcity of power crisis of our country, there is no other alternative but accessing renewable resources of our country. The research objective was to design a hybrid power system (solar-diesel generator) for a garment industry (Knit Concern's Ltd.), as the garments are the main source of employment and economy of the country. Details investigation was done on load consumption, location, available resources, feasibility etc. before designing the system. The system includes field data of specific site, cost analysis, proper components, operational lifetime, cost of servicing, spare parts availability etc. Despite of some limitation our system is able to supply energy to the load without any disruption. Though the system is not entirely renewable operated, still this could be a milestone for further work on this topic. 


\section{International Journal of Engineering Applied Sciences and Technology, 2019 \\ Vol. 4, Issue 8, ISSN No. 2455-2143, Pages 1-8 \\ Published Online December 2019 in IJEAST (http://www.ijeast.com)}

\section{REFERENCES}

[1] M. S. H. Lipu, M. S. Uddin, and M. A. R. Miah, "A Feasibility Study of Solar-Wind-Diesel Hybrid System in Rural and Remote Areas of Bangladesh," Int J Renew Energy Res, vol. 3, no. 4, pp. 892-900,

[2] B. Van der Zwaan and A. Rabl, "Prospects for PV: a learning curve analysis," Sol Energy, vol. 74, no. 1, pp. 19-31, 2003.

[3] S. Islam and A.-U. Huda, "Technical note Proper utilization of solar energy in Bangladesh: effect on the environment, food supply and the standard of living," Renew Energy, vol. 17, no. 2, pp. 255-263, Jun. 1999.

[4] M. H. Kabir, W. Endlicher, and J. Jägermeyr, "Calculation of bright roof-tops for solar PV applications in Dhaka Megacity, Bangladesh," Renew Energy, vol. 35, no. 8, pp. 1760-1764, 2010.

[5] M. LokeshReddy, P.J.R. Pavan Kumar, S.Aneel Manik Chandra, T. Sudhakar Babu, N.Rajasekar, "Comparative Study on Charge Controller Techniques for Solar PV System", $1^{\text {st }}$ Int. Conference on Power Engineering, Computing and Control, PECCON-2017, 2-4 March2017, VIT University, Chennai Campus.

[6] Muhammad Riazul Hamid, Jakaria Rahimi, Sabrina Chowdhury, T.M. Moniruzzaman Sunny, "Design and Development of a Maximum Power Point Tracking (MPPT) charge controller for Photo-Voltaic (PV) power generation system", American Journal of Engineering Research, Vol-5, Issue- 5, PP-15-22.

[7] J. P. Benner and L. Kazmerski, "Photovoltaic gaining greater visibility," IEEE Spectr., vol. 36, no. 9, pp. 34-42, Sep. 1999.

[8] K. Anam, H. A Bustam, "Power crisis and its solution Through Renewable Energy in Bangladesh" in Journal of Selected Areas in Renewable and Sustainable Energy, pp: 1318, September Edition 2011

[9] Md. Mazedul Islam, Adnan Maroof Khan and Md. Monirul Islam (February 2013). Textile Industries in Bangladesh and Challenges of Growth (PDF). Research Journal of Engineering Sciences (Report). pp. 31-37.

[10] http://blog.constellation.com/2016/03/25/led-vs-cflbulbs/. 